\title{
Allelotype Analysis
}

National Cancer Institute

\section{Source}

National Cancer Institute. Allelotype Analysis. NCI Thesaurus. Code C19823.

The examination of the extent and variation of allelic loss in polymorphic DNA markers within a sample. 